DOI: $10.17805 / z p u .2016 .3 .10$

\title{
Реальное и фантастическое в «Утопии» Т. Мора
}

\author{
Т. С. ПАНИОТОВА
}

(ЮЖНЫЙ ФЕДЕРАЛЬНЫЙ УНИВЕРСИТЕТ)

Статья посвящена рассмотрению соотношения факта и вымысла в романе “Утопия» T. Мора (1478-1535), великого гуманиста, стоящего у истоков английского Возрождения и эпохи Модерна. 500-летняя годовщина выхода в свет Libellus vere aureus, nec minus salutaris quam festivus, de optimo rei publicae statu deque nova insula Utopia служит прекрасным поводом для переосмысления исторического места произведения в мировой культуре. В статье раскрывается диалектика реального и фантастического, правды и вымысла в «Утопии».

По устоявшемуся мнению, «Утопия» Т. Мора сформировала парадигму нового литературного жанра и нового способа размышления о будущем в форме фантастики. Само название острова, основанное на игре слов ou-topos / eu-topos; различных мест и действующих лиц (город Амаурот - «туманный», река Анидр - Безводная, Гитлодей - «сведущий в чепухе» и т. п.), а также многие характеристики идеального обще- 
ства, слабо связанные с реальностью того времени, казалось бы, свидетельствуют об абсолютном господстве вымысла. Но ряд авторов считают иначе. Согласно Моргану книга Мора, взятая в целом, - не фантастика, а рассказ о путешествии в Перу. Другие авторы историчность и реалистичность “Утопии» усматривают в описаниях острова Куба, третьи находят сходство обычаев утопистов с обычаями коренных народов Америки, четвертые обращают внимание на адресный характер критики социальных порядков.

Для выяснения соотношения реального и вымышленного автор принимает во внимание всю совокупность обстоятельств, связанных с написанием «Утопии». Среди них: пребывание Мора в Антверпене в 1515 г.; присутствие реальных исторических лиц П. Эгидия (Петр Жиль), кардинала Дж. Мортона, и т. д. Следует учитывать источники, которые могли послужить основой информации о Новом Свете: письма Х. Колумба, дневники путешественников, вышедшую 1503 г. книгу А. Веспуччи «Новый Свет», «Декады» П. Мартира де Англериа.

К разнообразной информации о Новом Свете, где реальное было перемешано с фантастическим, Мор относился критически и с долей иронии. Далекий от беспочвенного фантазирования, мыслитель четко очерчивал круг своих интересов: социальные факторы процветания государства и общества.

Ключевые слова: утопия; Томас Мор; «Утопия»; реальное; фантастическое; социальная критика; Новый Свет; Христофор Колумб; история английской литературы

\section{ВВЕАЕНИЕ}

2016 год отмечен 500-й годовщиной выхода в свет «Утопии» Томаса Мора $2 \bigcup 16$ (1478-1535). Т. Мор, стоящий у истоков английского Возрождения и эпохи Модерна, создал произведение, влияние которого на гуманитарную науку и мировую литературу переоценить невозможно. «Утопия» сформировала парадигму нового литературного жанра и способа мышления. Можно смело утверждать, что практически все социальные утопии XVI-XX вв. - от «Города Солнца» Т. Кампанеллы до утопических проектов и практик XX столетия - восходят к произведению Т. Мора как к первоисточнику.

Бытующее в обыденном сознании и закрепившееся в научной литературе понимание утопии как фантазии, химеры, несбыточной мечты (Араб-Оглы, 2001; Kateb, 1972) на первый взгляд напрямую связано с исходным значением слова: ou-topos, т. е. «место, которого нет». Подобное понимание замыкает утопию в рамках вымышленного мира. Однако в современных исследованиях утопия понимается не столь однозначно. Насыщенная палитра мнений характеризуется амбивалентными трактовками: утопия как жанр (Trousson, 1995; Sargent, 1979) или как функция (Guldberg Cerutty, 1996; Roig, 1992); как всеобщий принцип бытия (Блох,1997; Ainsa, 1999) или как кабинетный опус (Сорель, 1908); как фальшивая ценность, несущая человечеству погибель и зло (Бердяев, 2010; Поппер, 1992), или как движущая сила истории (Манхейм, 1994; Ааски, 1991); как «гуманистическая религия», секуляризированная эсхатология (Buber,1966) или как научный метод мышления (Krismansky, 1963, Ruyer, 1950). Многие современные авторы отказываются от понимания утопии как чистой фантазии и настаивают на ее практической реализуемости. Аругие акцентируют внимание на особой - поисковой - роли вымысла. В частности, Р. Рюйе утверждал, что вымысел в утопии - не беспочвенная фантазия, он играет роль мысленного эксперимента.

В настоящей статье предпринята попытка выяснения соотношения факта и вымысла в «Утопии» Т. Мора. С этой целью были привлечены не исследованные ра- 
нее материалы, относящиеся ко времени написания произведения. Мы полагаем, что только помещение текста в конкретный исторический и социокультурный контекст позволит сделать обоснованные выводы по интересующей нас проблеме: насколько велика доля фантастического в әтом произведении и какова роль вымысла, к которому прибегает автор.

\section{КРАТКАЯ ХАРАКТЕРИСТИКА ПЕРВЫХ ИЗААНИЙ «УТОПИИ»: СРАВНИТЕАЬНЫЙ АНАИИЗ}

«Утопия» или «Весьма полезная, а также занимательная, поистине золотая книжечка о наилучшем устройстве государства и новом острове Утопия мужа известнейшего и красноречивейшего Томаса Мора, гражданина и шерифа славного

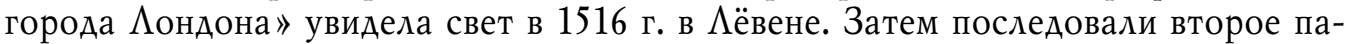
рижское издание (1517) и два базельских издания (оба вышли в свет в 1518 г.), все на латыни. После этого Мор занялся государственными делами и предоставил книгу ее собственной судьбе. Между четырьмя первыми изданиями много общего в структуре и содержании материала, но есть и отличия. В письме, посланном Мором Э. Роттердамскому в сентябре 1516 г., выражая свою воодушевленность с изданием книги, он просит друга организовать поддержку его Nusquamam со стороны лиц просвещенных и государственных. Эразм выполнил просьбу друга, и таким образом основной текст «Утопии» был дополнен серией различных рекомендательных документов, обычно называемых parerga. Это письма различных лиц, принадлежащих к кружку христианских гуманистов, восхваляющие Утопию поэмы, утопийский алфавит, поэма на утопийском языке с переводом на латынь и т. А. Все четыре издания включают письмо Мора к Петру Эгидию, выполняющее роль своеобразного предисловия. Кроме этого, первое и второе издания содержат короткие примечания-разъяснения и комментарии.

Между тем существуют некоторые существенные отличия между четырьмя первыми изданиями. Например, лёвенское и парижское издания включают письмо и поэму Аесмариаса, обращенную к Жилю, которые отсутствуют в базельских изданиях. Второе издание, единственное из всех, не содержит ни карты Утопии, ни утопийского алфавита, но здесь появляется второе письмо Мора к Жилю, а также обращение Аупсета к читателю. Эти документы отсутствуют в трех других изданиях. Ава издания 1518 г., очень похожие между собой, отличаются от предшествующих включением письма Эразма и отсутствием письма Аесмариаса, но главным образом тем, что они дополняются серией эпиграмм Мора и Эразма. Полное название книги звучало так: «Весьма полезная, а также занимательная, поистине золотая книжечка о наилучшем устройстве государства и новом острове Утопия мужа известнейшего и красноречивейшего Томаса Мора, гражданина и шерифа славного города Аондона. Эпиграммы известнейшего и красноречивейшего Томаса Мора, по большей части переведенные с греческого. Эпиграммы Аесидерио Эразма из Роттердама. В славном Базеле». Наконец, четвертый, и, как полагает Хосе Ауис Галимиди, наиболее полный и окончательный, вариант включал в себя следующие тексты:

- Эразм Роттердамский Иоганну Фробену, дражайшему куму своему шлет привет;

- Гилельм Бюде приветствует Томаса $\Lambda$ упсета, англичанина; 
- утопийский алфавит;

- посвященные острову Утопия стихи увенчанного поэта Анемолия внучатого племянника Гитлодея;

- карта Утопии;

- поэма, написанная на утопийском языке;

- Славнейшему господину Иерониму Буслидию - пробсту в городе Эр и советнику короля католиков Карла Петр Эгидий шлет привет;

- Иоганн Палудан из Касселя шлет привет Петру Эгидию;

- стихотворение ловенского ритора Иоганна Палудана, посвященное острову Утопия;

- Герард Новиомагийский об Утопии;

- Корнелий Графей - читателю;

- Иероним Буслидий шлет привет Томасу Мору;

- Томас Мор шлет привет Петру Эгидию;

- Первая книга беседы, которую вел Рафаил Гитлодей - человек выдающийся о наилучшем устройстве государства в передаче Томаса Мора, человека известного, гражданина и шерифа славного британского города

- Беседа Рафаила Гитлодея о наилучшем устройстве государства в пересказе Томаса Мора, лондонского гражданина и шерифа. Книга вторая;

— колофон (эмблема) печатного дома И. Фробейна (Galimidi: Электронный ресурс).

Титульный лист-бордюр для этого издания был исполнен гравюрой на дереве знаменитым художником и гравером Гансом Гольбейном Младшим (1494-1543).

\section{ПОА ИННЫЕ И ВЫМЫШАЕННЫЕ ГЕРОИ «УТОПИИ»}

Пребывание Мора в Антверпене в 1515 г. является доказанным фактом. Он был членом дипломатической миссии, направленной Генрихом VIII для урегулирования торговых споров с испанской стороной. Аетом Мор пребывал в Брюгге, в сентябре - в Брюсселе, в октябре - в Антверпене, и в ноябре он вернулся в Аондон. Именно в Антверпене Мор написал бо́льшую часть своей книги.

Петр Эгидий (Петр Жиль), которому Мор направляет письмо, предваряющее «Утопию», и который якобы познакомил Мора с Гитлодеем, - реальное историческое лицо. В 1515 г. он был секретарем суда в городе и принадлежал к кружку гуманистов. Так же как и Мор, он был другом Эразма Роттердамского. Т. Мора и Э. Роттердамского связывали теплые отношения. Именно Мора пригласил Эразм для перевода Аукреция, именно Мору он посвятил свою сатиру «Похвала глупости». Весной 1515 г. Эразм был в Аондоне, где вручил Мору рекомендательное письмо для Петра Эгидия.

Историческим лицом является кардинал Ажон Мортон, архиепископ Кентерберийский (1420-1450). В 1493 г. Папа Александр VI сделал его кардиналом, а Генрих VII - советником лорд-канцлером королевства. Это реальное и очень влиятельное историческое лицо из плоти и крови. Мор служил у него пажом, и именно Мортон содействовал направлению юноши в Оксфорд.

Ажон Клемент - еще один участник бесед - служил пажом, был секретарем или помощником Мора в 1515 г., позднее он женился на Маргарет Ажигс, молочной сестре Алисии, дочери Мора, и закончил жизнь известным врачом. 
Высказываются предположения об исторической достоверности еще одного участника бесед - «благочестивого юноши и теолога по профессии», горевшего желанием отправиться на остров Утопия в качестве проповедника, чтобы нести утопийцам христианскую веру. Это либо Ажон Мейер, который, будучи теологом Парижского университета в период с 1505 по 1530 г., одним из первых заинтересовался американскими проблемами, либо викарий Ковланд Филипс, известный в те времена проповедник (Borges Morán, 1995: 96).

Вне всякого сомнения, реалистична фигура Америго Веспуччи (1451-1512). Этот мореплаватель осуществил четыре путешествия в Америку, два из которых под флагом испанской Короны и два других - под португальским флагом. Во время первого путешествия он исследовал побережье Северной и Центральной Америки, а во время трех последующих - бразильское побережье. Причем согласно комментариям самого Веспуччи, четвертое путешествие должно было состояться в сторону Малаки и Калькутты, и только по капризу капитана Гонсало Гоэльфо

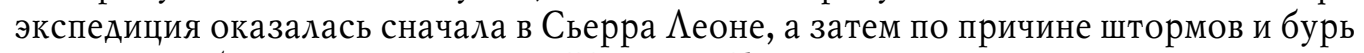
вынуждена была изменить курс с Индии на Бразилию.

Поскольку ни в одном из писем Веспуччи ничего не говорится о сопровождавших его моряках, воображение Мора смогло совершить практически невозможное: обеспечить присутствие португальца Гитлодея на испанских кораблях, где сам Веспуччи был не капитаном, а всего лишь кормчим. Но то, что соответствует реальности, так это оставление в одной из крепостей отряда из 24 человек во время его четвертого путешествия. Об этом событии упоминает и Мор.

Весьма правдоподобно описывает Мор и вымышленных героев, в первую очередь Гитлодея. Это правдоподобие позволило некоторым современным исследователям предположить, что португалец - вполне реальное историческое лицо, возможно, обучавшееся космографии в Школе Сагреса. Однако другие авторы подвергают сомнению эту позицию, поскольку школа эта никогда не занималась подготовкой будущих космографов и вскоре после кончины ее основателя Энрике эль Навеганте (1394-1460) исчезла.

\section{СТРУКТУРА «УТОПИИ»: ПРЕАНАЗНАЧЕНИЕ ЕЕ ЧАСТЕЙ}

Произведение состоит из двух книг и ряда документов второго плана, представляющих своеобразное обрамление основного текста и именуемых Хосе Ауисом Галимиди parerga.

Первое место в parerga по праву принадлежит посланию Мора к Жилю, представленному в первых четырех изданиях в качестве предисловия. Этот текст не может не порождать у читателя определенное беспокойство, связанное с содержанием «Утопии», поскольку не оправдывает законных ожиданий более правдоподобного по сравнению с основным текстом комментария. Напротив, отправитель письма ведет себя как актер, который, оставаясь в уличном убранстве на фоне еще не поднятого занавеса, обращается к публике, произносит речи хорошо поставленным голосом и принимает театральные позы, как будто бы спектакль, которому еще только предстоит разыграться на книжной сцене, уже начался. Аействительно, Томас Мор со всей серьезностью пишет, что, создавая «Утопию», он рассчитывал лишь на свою память, а потому, сомневаясь в точности воспроизведения деталей бесед в Амстердаме, просит Петра Эгидия показать текст Гитлодею. 
В этом письме - предисловии к фактически еще не опубликованной книге Мор сообщает о глубоком впечатлении, которое произвел на всю Европу рассказ (существующего лишь в авторском воображении) Гитлодея о наилучшем устройстве государства, и еще более усиливает эффект правдоподобия, добавляя, что один теолог-проповедник жаждет отправиться в Новый Свет с миссией христианизации коренного населения.

Аругие документы, составляющие parerga «Утопии», поддерживают тон, заданный письмом-предисловием, продолжая игру на грани правды и вымысла. Многие гуманисты, представляющие книгу, подписываются своими именами, ставят дату и место создания рекомендательного письма и в равной степени восхваляют как автора и его произведение, так и Гитлодея и идеальное государство Утопию, как если бы они были не эйдосами, а существовали в реальном мире. Бюде, например, спрашивает, как утопийцам удалось избежать всех тех пороков, от которых страдает современное европейское общество, а Жиль, вспоминая некоторые детали разговора в Амстердаме, прилагает к своему письму четверостишие на утопийском языке, которое ему якобы прислал Гитлодей (Мор, 1978: 98). Вымысел ищет подтверждение в другом вымысле, и таким образом, например, Анемолий, автор шестистишия и «внучатый племянник» Гитлодея, носит то же имя, что и анемолиты - соседи утопийцев.

Таким образом, получается, что хотя все авторы parerga по отведенному им автором месту находятся за границей текста, который рекомендуют читателю, они претендуют на то, чтобы стать участниками сюжета. Помещая Рафаила Гитлодея, его родню и остров Утопия на один уровень с Т. Мором, его семьей и Англией, они еще больше осложняют восприятие истинности основного содержания «Утопии», разделяя с автором ответственность за описание и ценностные суждения. И даже те, кто ничего не говорит об острове или философе-путешественнике, исключительно положительно оценивают принципы утопического общества, распространяя за пределами основного текста идеи, исходящие из его центра, т. е. двух книг, на которые распадается текст «Утопии».

Общая логика произведения такова, что от полилога с участием многих действующих лиц постепенно совершается переход к монологу главного персонажа Гитлодея, а вслед за критикой европейских порядков следует описание идеального общества.

Первая книга начинается рассказом, в котором Т. Мор посвящает читателя в детали продолжительного дружеского разговора, который состоялся в Антверпене в 1515 г. во время короткого отдыха после выполнения им дипломатической миссии в Брюсселе. Мор говорит о том, что близкий друг Петр Жиль представил ему странствующего философа из Португалии, участника экспедиций Америго Веспуччи в Новый Свет. Португалец не только был особой, философски мыслящей, образованной, но и имел за плечами разнообразный опыт и мог многое поведать о местах и народах, с которыми он познакомился во время путешествий.

Беседа, которую ведут Мор, Жиль и Гитлодей, включает три части. В первой Рафаэль вспоминает основные моменты встречи в доме кардинала Мортона, когда философу пришлось дискутировать с некоторыми гостями и хозяином дома о несправедливости системы наказаний в Англии, о социальной и экономической ситуации в стране и т. А. Он обращал внимание на обезземеливание и обнищание 
английского крестьянства в результате превращения земельных угодий в пастбища для овец; связанный с этим рост воровства, разбоя, бродяжничества; принятие государством несправедливых законов против бродяг, вплоть до осуждения на смертную казнь; продажность судей; огромное количество знати, живущей праздно; содержание огромных армий, опустошающих казну, бесконечные войны, которые ведут европейские государи, одержимые территориальными и политическими амбициями. Английской системе правления он противопоставлял государство полилеритов, «соседей» персов, которые, за исключением дани, платимой ими ежегодно персидскому царю, в остальном совершенно свободны и руководствуются своим справедливым законам. Уже здесь во вполне, казалось бы, реалистическое повествование вплетаются фантастические нити, поскольку таких соседей у персов в природе никогда не существовало.

Вторая часть представляет собой обмен мнениями между Мором и Гитлодеем по поводу практической и моральной целесообразности использования знаний и опыта Гитлодея (равно как и любого другого философа или образованного и знающего человека) при дворе, на службе у сильных мира сего. На вопрос Мора, почему такой просвещенный человек, как Гитлодей, не служит при дворе, чтобы давать мудрые советы государям, португалец отвечает, что правители не думают о хорошем правлении; их интересуют только войны, налоги, обретение новых владений. Аа и вряд ли возможно справедливое правление там, где все мерят на деньги и где существует частная собственность.

Наконец, третья линия, развитию которой посвящена вся вторая книга «Утопии», сводится к детальному описанию географических, политических, экономических, социальных и религиозных аспектов устройства острова Утопия, к берегам которого по чистой случайности причалил Рафаэль более пяти лет тому назад. Эта вторая часть книги несет основную смысловую нагрузку, а все прочие рассуждения о европейском обществе лишь оттеняют совершенство утопического общества.

На первый взгляд сюжет второй книги «Утопии» крайне прост и представляет собой рядовой рассказ о путешествии в далекие страны, подобный романам-путешествиям Эвгемера и Ямбула эпохи эллинизма. Однако при более глубоком рассмотрении возникают некоторые сомнения. С одной стороны, обе книги написаны так, что любому мало-мальски проницательному читателю, даже не слишком сведущему в вопросах географии, становится ясно, что Рафаэль, остров Утопия с его установлениями и жителями, а также другие народы, земли и обычаи, упоминаемые в книге, но неизвестные европейцам, - это плоды фантазии Т. Мора. Собственно, на это намекает и сам автор, называя свою страну Nusquama (Нигдея, «не существующая ни в одном месте»), ее столицу - Амауротом (《туманным»), главную реку - Анидр ( «безводной»), давая путешественнику имя Гитлодей, что означает «болтун», «шарлатан». Но с другой стороны, элементы вымысла здесь плотно и порой загадочно стыкуются с реальными персонами, местами и событиями, легко проверяемыми и удостоверяемыми. Так, главный литературный персонаж, Гитлодей, с легкостью «вступает в отношения» с реальными историческими лицами: «ведет диалоги»с кардиналом и лорд-канцлером королевства Аж. Мортоном; «сопровождает в плавании» Америго Веспуччи; пространно «рассказывает» Т. Мору и П. Эгидию о своем пятилетнем пребывании на острове Утопия и т. А. 
Такой подход пронизывает все содержание «Утопии», и, формируя двойственное отношение к истине, подменяя правдивость - правдоподобием, он вдияет на восприятие всех ценностных суждений, содержащихся в тексте. А в «Утопии» остро и глубоко обсуждаются весьма серьезные темы: каково наилучшее устройство государства, какие моральные и христианские принципы направляют политическое и экономическое развитие Европы; какой должна быть позиция философа по отношению к власти и проводимой ею политике. Но тот факт, что один из двух основных участников диалога - это вымышленный персонаж, хотим мы этого или нет, делает персонажем и второго участника диалога, как бы тот ни прикрывался именем автора. Здесь восприятие и герменевтика «Утопии» непосредственно соприкасаются с ответом на вопрос, какой из персонажей книги наиболее выражает философскую позицию ее автора и что же в конечном счете послужило поводом к ее написанию.

\section{ИСТОРИЧЕСКОЕ И ФАНТАСТИЧЕСКОЕ В ОПИСАНИЯХ НОВОГО СВЕТА}

Как утверждает испанский философ-эссеист Ф. Аинса, появление «Утопии» стало результатом «культурного шока», испытанного Мором при чтении писем и дневников путешественников, сообщающих о Западных Индиях. По мнению Е. Имаса, именно «открытие Америки... сделало возможным рождение утопии, путешествие Гитлодея, воображаемого спутника Америго Веспуччи» (Imaz, 1982: 13). Х. А. Абельян утверждает, что Америка стала вдохновлять Мора, начиная с публикации в 1503-1504 гг. Mundus Novus Америго Веспуччи, когда в общественном сознании стала укореняться идея, что «Америка, в сущности, и есть утопия» (Abellan, 1986: 391). Однако A. Рамос настаивает, что «двигателем импульса Мора» скорее всего было издание De Orbe Novo Decades Педро Máртира де Англериа в 5011 г. При этом находятся авторы, которые утверждают, что существуют доказательства, что книга Мора - это не фантастика, а рассказ о путешествии в Перу и о том, что путешественник там увидел (Morgan, 1946).

Комментируя эти высказывания, следует заметить, что на момент написания «Утопии» развитые цивилизации Америки еще не были открыты и никакой информацией о «превосходно управляемых республиках», о которых повествует Гитлодей, европейцы не располагали. Никто из путешественников не писал об «оптимальном состоянии государства», а также о просвещенных гражданах, живущих далеко за океаном. Напротив, классическая европейская литература, интерес к которой необычайно возрос в эпоху Ренессанса, содержала такие описания. Начиная с Платона, труды которого прекрасно знал Т. Мор (свидетельством чему являются многочисленные ссылки на античного философа в тексте «Утопии»), проблема образцового устройства государства превратилась в постоянную тему для обсуждения.

Что же касается Нового Света, куда Мор помещает Утопию, то сведения о нем он мог получать из самых разных источников, включая беседы, которые велись при королевском дворе, или слухи, бродившие в обществе. Среди прочего необходимо выделить следущее.

1. Письмо Колумба, изданное в Антверпене летом 1493 г., содержащие важные сведения о Новом Свете (Colón: Электронный ресурс). 
2. Издание Cosmographiae introductio cum quibusdam geometriae ac astronomiae principiis ad eam rem necessariis. Insuper quatuor Americi Vespucii navigationes. Universalis Cosmographiae descriptio tam in solido quam plano, eis etiam insertis, quae Ptholomaeo ignota a nuperis reperta sunt (1507), сопровождаемое письмами А. Веспуччи, содержащее дополнительные сведения и характеристики Нового Света (Briesemeister, 2000: Электронный ресурс).

3. Получаемые сведения Мором в период его службы при дворе Генриха VIII, супругой которого в 1509 г. стала Екатерина Арагонская, дочь Католических Королей.

4. «Аекады» П. Мартира де Англериа, королевского историографа, изданные в Севилье в 1511 г., представлявшие собой собрание полученной, в том числе из первых рук, информации о Новом Свете.

5. Наблюдение и осмысление некоторых «диковинок», свидетелем которых мог быть Мор, а именно: представление Генриху XVIII в Аондоне трех индейцев (около 1502 г.); затем и шести других, привезенных монахами-францисканцами.

Самые начальные сведения о новых землях содержались в первом письме Христофора Колумба об открытии «Западных Индий». За очень короткое время оно было напечатано в Амстердаме (1493), Барселоне (1493), Базеле (1493-1494), выдержало в течение года три издания в Париже (1493) и позднее в Страсбурге (1497), а затем уже в списках разошлось по другим странам и городам. Как справедливо указывает А. Рамос, «сочинения Христофора Колумба, особенно его дневник, имеют первостепенное значение, как бесценные источники познания фактов эпохи географических открытий» (Ramos, 1981-1982: 9), они похожи на исторические документы, однако, строго говоря, таковыми не являются, поскольку реальные факты здесь перемешаны со слухами и вымыслами.

Письма Колумба не были единичным фактом: также печатаются дневники путешественников, письма, отчеты, повествующие о чудесах Нового Света, еще сильнее разжигающие любопытство публики. Среди прочих нельзя не упомянуть труды королевского историографа Педро Мартира де Англериа: написанные на латыни Opus epistolarum и De Orbe Novo Decades. Первым и главным информатором Мартира был сам X. Колумб, с которым хронист был знаком лично, а также находившиеся при дворе члены семьи адмирала и его спутники. От них историограф получил чрезвычайно ценные сведения антропологического и этнологического свойства о коренных жителях открытых земель, которые могли заинтересовать Т. Мора. Так, например, в письме Иуису Уртадо де Мендоса от 18 декабря 1513 г. Мартир писал о том, что в тех широтах обитает огромное количество народностей, которые значительно отличаются друг от друга по своим обычаям. Есть среди них карибы или каннибалы, которые питаются человеческим мясом, стреляют отравленными стрелами. Аругие же народности любезны и гостеприимны. Живут они счастливо на холмах и берегах рек (цит. по: Amarillis Vicente: Электронный ресурс).

Аругим источником являются работы, приписываемые Америго Веспуччи. В первую очередь это дневник его путешествий, который был издан Вальдземюллером под названием Quatuor navigationes. И именно на книгу Вальдземюллера ссылался в «Утопии» Т. Мор, сообщая, для пущей достоверности, что рассказчик Гитлодей был постоянным спутником Америго Веспуччи «в трех последних стран- 
ствиях из четырех, про которые уже все повсюду читают» (Мор, 1978: 119-120; курсив наш. - T. П.). Аействительно, в то время когда Мор находился в Амстердаме в октябре 1515 г., все зачитывались рассказом об этих четырех путешествиях, описанных А. Веспуччи.

Важно понять: какого рода сведения о Новом Свете использовал Т. Мор при создании своей модели «наилучшего устройства государства ?? Ведь сведения эти были весьма разнородны: от описания различных чудес и несуществующих в природе монстров - до реалистичных картин природы, общественного устройства, обычаев и нравов коренных народов Америки. Разнилось и восприятие коренного населения: от жестоких варваров - до добрых дикарей.

Мог ли Мор почерпнуть хоть какую-то позитивную информацию из упомянутых источников при конструировании своей модели идеального государства? В первую очередь приходят в голову присутствующие в текстах путешественников образы чудом сохранившегося золотого века с природным изобилием и естественным миропорядком. Приведем несколько выдержек из письма Х. Колумба: «Жители этого и всех других островов... все как мужчины, так и женщины ходят нагишом, в чем мать родила... У них нет ни железа, ни стали, ни [железного] оружия, да и не привыкли они пользоваться им, и не потому, что они недостаточно умелы... а потому, что они на удивление робки»; «...если у них попросить какую-нибудь вещь, они никогда не откажутся ее отдать»; «...они не ведали ни ереси, ни идолопоклонства, а верили, что имеются на небесах некие силы... и твердо стояли на том, что я и мои корабли и мои люди явились с неба»; «...у них очень острый ум»; «...если иметь в виду... намерение Ваших Высочеств обратить их в нашу святую веру, к чему они очень расположены». Наконец, общий вывод: «Край этот поистине желанный, и, раз увидев его, покинуть его невозможно уже никогда» (Colón: Электронный ресурс).

Также и в первой Аекаде П. Мартира де Англерии, к которой постоянно апеллирует A. Рамос, содержится описание аборигенов, которые «живут в золотом веке, нагие, без мер и весов, без мертвящих денег, без законов, без продажных судей, без книг, довольствуясь природой, живут, не задумываясь о будущем...» (Mártir de Angleria, 1989: 145-146); «...они считают истиной, что земля, так же как солнце и вода, являются общими, и что не должно быть ни “твоего", ни “моего", как зерна, из которого произрастает все зло... Они не разделяют свои наделы ни заборами, ни рвами, ни изгородями... и считают злым и нечестивым того человека, которому доставляет удовольствие обижать других людей» (там же: 201-202). Присутствуют характеристики Нового Света в стиле золотого века также и у Веспуччи: «Нет у них тканей ни из шерсти, ни изо льна, ни даже ситца, потому в ни в чем из этого они не нуждаются. Нет у них также и собственного имущества, потому что все у них общее. Живут вместе без королей, без власти, и каждый из них - господин самого себя» (Vespucio, 1985: 61).

Наряду с этими вполне реалистическими описаниями встречаются совершенно фантастические, в которых негативные характеристики и оценки доминируют. Колумб писал: «Я также узнал, что далеко отсюда есть люди с одним глазом и другие с собачьими мордами, которые едят людей, и что, поймав человека, ему отрубают голову, пьют кровь и разрубают тело на части»; «...рассказывают, что есть люди, у которых только один глаз на лбу, и другие, которых зовут каннибалами»; в од- 
ной из провинций якобы видели людей с хвостами, а в третьей - сирен, которые оказались вовсе «не такими прекрасными, как их описывают» (Colón: Электронный ресурс).

Преимущественно негативно отзывался о бразильских индейцах А. Веспуччи: «...их образ жизни крайне варварский», они практикуют «варварские церемонии», наконец, «эти народы хуже животных» (Vespucio, 1985: 79-80, 82, 83, 87, 105). П. Мартир, так же как и многие другие хронисты, не жалел ярких красок для описания диких обычаев индейцев. Вот как он описывал «кулинарные традиции» каннибалов: «Аетей, которых ловят [каннибалы], они кастрируют, как мы цыплят или поросят, если хотим, чтобы они выросли толстыми и с нежным мясом; когда они вырастают большими и тучными, их съедают; но если в их руки попадают мужчины средних лет, то их убивают и разделывают; кишки и ступни ног едят свежими, а сами ноги засаливают, как мы свиные окорока. Есть женщин у них считается незаконным и непристойным, но если им удается поймать несколько молодых женщин, за ними ухаживают и сохраняют для производства потомства не иначе, чем мы поступаем с курами, овцами, телками и другими животными. Пожилых женщин они превращают в рабынь, чтобы они им прислуживали» (Martir de Angleria, 1989: 12).

Однако вся эта «экзотика»- как «райская», так и «адская»- не представляет интереса для Мора. Поэтому, комментируя рассказ Гитлодея, он замечает: «Особенно полезно будет не пропустить прежде всего те дела, разумные и верные, которые он замечал где-либо у народов, живущих вместе, как это подобает гражданам... Расспросы о чудищах мы пока оставили, так как в этом мало нового. Ибо где только не найдешь ты хищных Сцилл, Келен, народопожирателей Аестригонов и подобных им громадных чудищ, но граждан с мудрыми устоями жизни ты, конечно же, не везде найдешь» (Мор, 1978: 122-123).

В этом контексте, и в особенности в связи с Америкой, главная роль, на наш взгляд, принадлежит фрагменту, где Мор устами Гитлодея рассказывает историю мудрого правителя Утопа, который более тысячи лет тому назад попал на остров в результате кораблекрушения, завоевал его и «привел скопище грубого и дикого народа к такому образу жизни и такой просвещенности, что ныне они превосходят в этом почти всех смертных» (там же: 172). И если следовать логике лорд-канцлера, то для того чтобы государство обрело разумный способ правления и процветания, достигло наибольшего счастья, необходимо, чтобы не знающий собственности, но способный к наукам и ремеслам «естественный человек», усвоил все то, что было «хорошо придумано» более развитыми народами, а также чтобы нашелся мудрый правитель, способный выполнить цивилизаторскую миссию. А если учесть, что в качестве спутников Утопа называются египтяне и римляне, а на Платона, как на непререкаемый авторитет, Мор постоянно ссылается на страницах своей книги, то совпадение некоторых положений «Государства» (отсутствие собственности у стражей) с описаниями образа жизни автохтонных народов, считавших, что «не должно быть ни твоего, ни моего», могло стать необходимым и достаточным основанием для превращения принципа общности имуществ в краеугольный камень моровской концепции.

Следует обратить внимание на островное положение совершенного государства. А. Рамос, опираясь на издание Первой Аекады П. Мартира в 1511 г., доказыва- 
ет, что из ее содержания следует, во-первых, «наличие всего необходимого для счастья у индейцев Эспаньолы», а во-вторых, изолированность острова, «который подобно Утопии отделен от континента узким проливом (в качестве такового также рассматривался остров Хуана, или Куба)»(Ramos, 1985: 234). О сходстве острова Утопия и острова Куба писал в XX в. Э. Мартинес Эстрада в своей работе «Новый Свет, остров Утопия и остров Куба» (Martinez Estrada, 1963: 89-122). К моменту написания «Утопии» уже было доказано, что Америка - не остров, как предполагал Колумб, а материк. Исходя из этой информации, Мор вполне мог бы разместить свое государство где-нибудь на незаселенных, согласно карте Вальдземюллера, землях материка. Однако он предпочел как островную форму, так и старое название - не Америка, а Новый Свет, поскольку именно оно (Mundo Nuevo - с исп. Новый Мир) наилучшим образом ассоциировалось с идеей нового, ни на что не похожего государства Утопии. Свойственные островной форме автаркия и изолированность проявятся в книге Т. Мора, а затем превратятся в два важнейших признака классической модели утопии.

\section{ЗАКАЮЧЕНИЕ}

Все сказанное выше позволяет сделать ряд выводов.

Мор был далек от установки на природное изобилие как условие беззаботной счастливой жизни, характерной для находящихся под влиянием мифа утопий; от идеализации «доброго дикаря», свойственной многим его современникам и последователям; его не интересовали различного рода чудеса и заморские диковинки. К получаемой из различных источников информации, где реальное было перемешано с вымыслом, он относился критически и с долей иронии. Аалекий от беспочвенного фантазирования, Мор четко очерчивал круг своих интересов: социальные факторы процветания государства и общества. Об общественной собственности писали предшественники - Платон, отцы церкви, и тот факт, что она чудесным образом сохранилась за океаном у неиспорченных цивилизацией народов Америки, являлось для мыслителя лишним доказательством реалистичности и жизненности данного установления. Он воспринял и перенес в «Утопию» из автохтонных порядков и некоторые другие характеристики: обязательность и всеобщность труда, религиозную толерантность, презрение к золоту и драгоценностям и т. А. Разумеется, во времена создания «Утопии» эти принципы могли показаться чистым вымыслом, хотя на деле относились к историческим фактам. Не был вымыслом и предпринятый Мором критический анализ европейских порядков.

Каково же в таком случае соотношение правды и вымысла в произведении? Можно говорить о диалектическом взаимодействии реального и фантастического, правды и вымысла. В «Утопии» правда (исторические лица, события) служит обоснованию вымысла, превращая его в правдоподобие; кажущееся фантазией обретает в тексте реальную жизнь и доказательность; в фантастических образах предстает подлинный, т. е. достойный человека, мир. Главное предназначение вымысла зримо представить возможное.

Разумеется, сквозь призму времени многое в утопических образах кажется простым, наивным и даже недостойным человека. Однако это не умаляет значения произведения, легшего в основу целого направления общественной мысли и оказавшего влияние на ход мировой истории. 


\section{СПИСОК АИТЕРАТУРЫ}

Араб-Оглы, Э. А. (2001) Утопия и антиутопия // Философский словарь / под ред. И. Т. Фролова. М. : Республика. 719 с. С. 590-592.

Бердяев, Н. А. (2010) О рабстве и свободе человека. М. : АСТ. 320 с.

Блох, Э. (1997) Тюбингенское введение в философию. Екатеринбург : Изд-во Уральского ун-та. 395 с.

$\Lambda$ аски, М. (1991) Утопия и революция / пер. $\Lambda$. Седова // Утопия и утопическое мышление : антология зарубежной литературы / сост., общ. ред. и предисл. В. Чаликовой. М. : Прогресс. 408 с. С. $170-210$.

Манхейм, К. (1994) Аиагноз нашего времени. М. : Юрист. 700 с.

Мор, Т. (1978) Утопия : пер. с лат. М. : Наука. 416 с.

Поппер, К. (1992) Открытое общество и его враги : в 2 т. : пер. с англ. / под ред. В. Н. Садовского. М. : Феникс, Международный фонд «Культурная инициатива». Т. 1. Чары Платона. $448 \mathrm{c.}$

Сорель, Ж. (1908) Введение в изучение современного хозяйства. М. : Изд-во В. И. Иванова. $260 \mathrm{c}$.

Abellan, J. L. (1986) Historia critica del pensamiento espanol. 2-a ed. Madrid : EspasaCalpe. T. 2. La edad de Oro. 698 p.

Ainsa, F. (1999) La Reconstruccion de la Utopia. Mexico. Correo de la UNESCO. 238 p.

Angleria Martir de, P. (1989) Decadas del Nuevo Mundo. 1a ed. Madrid : Ed. Polifemo, XLIII, $566 \mathrm{p}$.

Amarillas, V. J. A. Pedro Mártir de Angleria, contino real y cronista de Castilla. La invencién de las nuevas Indias [Электронный ресурс] // Institución Fernando el Católico. URL: http://ifc.dpz.es/recursos/publicaciones/33/63/10armillas.pdf (дата обращения: 10.06.2016).

Borges Morán, P. (1995) Inspiración americana de la Utopia de Tomás Moro // Mar Oceana: revista del humanismo español e iberoamericano. № 2. P. 91-111.

Briesemeister, D. (2000) Las cartas de Amerigo Vespuci sobre el Nuevo Mundo [Электронный ресурс]// Olivar. Vol. 1. No. 1. P. 43-64. URL: http://www.olivar.fahce.unlp.edu.ar (дата обращения: 04.09.2015).

Buber, M. (1966). Caminos de utopía. México, FCE. 204 p.

Cerutti, G. H. (1996) Teoría de la utopía? // Agüero, O., Cerutti, H. (eds.). Utopía y nuestra América. Quito : Ed. Abya-Yala. 108 p. P. 93-108.

Colón, C. La Carta de Cristóbal Colón anunciando el descubrimiento [Электронный ресурс]// Antologia del Ensayo. URL: www.ensayistas.org/antologia/XV/colon/ (дата обращения: 01.06.2016).

Galimidi, J. L. La verdad y su recepcion en Utopía de Tomás Moro [Электронный pecypc]// UDESA - Universidad de San Andr?s. URL: http://live.v1.udesa.edu.ar/files/UAHumanidades/EVENTOS/PaperGalimidi101207.pdf (дата обращения: 01.06.2016).

Imaz, E. (1982) Topía y Utopía en Utopías del Renacimiento (1a. ed. 1941). Estudio preliminar // Utopias del renacimiento: Utopia, La Ciudad del Sol, Nueva Atlantida. Mexico : Fondo de Cultura Económica. P. 7-25.

Kateb, G. (1972) Utopia and Its Enemies: Studies in the Libertarian and Utopian Tradition. New York: Schocken Books. 244 p.

Krismansky, H. J. (1963) Die utopische metod. Koln; Opladen: Westdentscher Verlag. 159 s.

Martinez Estrada, E. (1963) El Nuevo Mundo, la isla de Utopia y la isla de Cuba // Cuadernos americanos. № 2. P. 89-122.

Morgan, E. A. (1946) Nowheare was somewhere: How History makes Utopias and How Utopias make History. Chapel Hill: The University of North Carolina Press. 234 p. 
Ramos, P. D. (1981-1982) Variaciones ideologicas en torno al Descubrimiento de America. Pedro Martir de Angleria y su mentalidad. Valladolid, Cuadernos Colombinos X. Casa-Museo de Colon \& Seminario Americanista. 84 p.

Roig, A. A. (1987) La utopía en el Ecuador (Estudio, introducción y selección de Arturo Andrés Roig). Quito: Banco Central del Ecuador; Corp. Ed. Nacional. 468 p.

Ruyer, R. (1950) L' Utopie et les utopies. Paris : Press Universitaires de France. 293 p.

Trousson, R. (1995) Historia de la literatura utópica. Viajes a países inexistentes, Barcelona : Península. $384 \mathrm{p}$.

Sargent, L. (1979) British and American Utopian Literature, 1516-1975. Boston: G. K. Hall $\&$ Co. 559 p.

Vespucio, A. (1985) El Nuevo Mundo. Viajes y documentos completos. Madrid : Akal. $144 \mathrm{p}$.

Аата поступления: 12.06 .2016 г.

\section{THE REAL AND THE FANTASTIC \\ IN THOMAS MORE'S “UTOPIA” \\ T. S. PANIOTOVA \\ (SOUTHERN FEDERAL UNIVERSITY)}

The article considers the correlation of fact and fiction in Thomas More's "Utopia". Thomas More (1478-1535) is an outstanding humanist, the pioneer of the English Renaissance and Modernity. This year marks the 500th anniversary of its publication. The jubilee of the "Libellus vere aureus, nec minus salutaris quam festivus, de optimo rei publicae statu deque nova insula Utopia" offers a fine opportunity to rethink the historical significance of this book for the world literature. Almost all subsequent social projects - from Thommaso Campanella's City of the Sun to 20th century utopian designs - point back to "Utopia" as their primary source. The course of history could have been different without these ideas and practices.

The article traces the dialectics of the real and fantastic, truth and fiction in "Utopia". It is traditionally held that More's book laid the foundation of a new genre - that of social criticism in the form of speculative fiction, "Utopia" is also believed to have developed a new way of thinking about future in the form of the fantastic. The name of the island based on the pun of ou-topos / eu-topos, as well as the names of various locations and characters (Amaurot "foggy", the Anider - "anhydrous", Hythloday - "versed in nonsense", etc.) and numerous other characteristics of the ideal society, seem to prove the absolute priority of fiction in More's text, having little connection with the reality of his times.

Some authors (A. Morgan, H. Herzog, E. Estrada, etc.), however, defend the opposite point of view. According to A. Morgan, More's book is not that of fictional fantasy, but a story about a journey to Peru. Other authors find the historicity and reality of "Utopia" in descriptions of Cuba, while still others point at the similarities between the customs of the Utopians and traditions of the indigenous peoples of America. Some researchers have noted that More's social criticism addresses specific issues of his times.

We have considered all of these points to find out the correlation of the real and the fictional in "Utopia", including the circumstances of More's staying in Antwerp in 1515, or the presence of real historical figures (Peter Egidius (Peter Giles), cardinal George Morton, etc.) in his book. We also address the important sources of information about the New World which More could have been familiar with, such as the letters of Columbus, travellers' diaries and memoranda, "Decades" by P. Martyr de Angleria, "El Nuevo Mundo" ("The New World") by A. Vespucci (publ. 1503), etc. 
More's attitude to the information about the New World where the real and the fantastic were deeply mixed was, in fact, critical, with a good deal of irony. The great thinker explicitly outlined his interests in writing "Utopia" - social factors of the state's and society's prosperity.

Keywords: "Utopia"; Sir Thomas More; fiction; fact; the real; fantastic; America; England; the New World

\section{REFERENCES}

Arab-Ogly, E A(2001) Utopiia i antiutopiia. In: Filosofskii slovar' / ed. by I. T. Frolov. Moscow, Respublika. 719 p. Pp. 590-592. (In Russ.).

Berdiaev, N. A. (2010) O rabstve i svobode cheloveka. Moscow, AST. 320 p. (In Russ.).

Bloch, E. (1997) Tiubingenskoe vvedenie v filosofiiu. Ekaterinburg, Izd-vo Ural'skogo un-ta. 395 p. (In Russ.).

Laski, M. (1991) Utopiia i revoliutsiia, transl. L. Sedova. In: Utopiia i utopicheskoe myshlenie : antologiia zarubezhnoi literatury / comp. \& ed. by V. Chalikova. Moscow, Progress. 408 p. Pp. 170-210. (In Russ.).

Mannheim, K. (1994) Diagnoz nashego vremeni. Moscow, Iurist. 700 p. (In Russ.).

More, Th. (1978) Utopiia. Moscow, Nauka. 416 p. (In Russ.).

Popper, K. (1992) Otkrytoe obshchestvo i ego vragi: in 2 vol. / ed. V. N. Sadovskii. Moscow, Feniks, Mezhdunarodnyi fond «Kul'turnaia initsiativa». Vol. 1. Chary Platona. 448 p. (In Russ.).

Sorel', Zh. (1908) Vvedenie v izuchenie sovremennogo kboziaistva. Moscow, V. I. Ivanov Publ. 260 p. (In Russ.).

Abellan, J. L. (1986) Historia critica del pensamiento espanol. 2nd edn. Madrid, EspasaCalpe. Vol. 2. La edad de Oro. 698 p. (In Spanish).

Ainsa, F. (1999) La Reconstruccion de la Utopia. Mexico. Correo de la UNESCO. 238 p. (In Spanish).

Angleria Martir de, P. (1989) Decadas del Nuevo Mundo. Madrid, Ed. Polifemo. XLIII, 566 p. (In Spanish).

Amarillas, V. J. A. Pedro Mártir de Angleria, contino real y cronista de Castilla. La invencién de las nuevas Indias. Institución Fernando el Católico [online] Available at: http://ifc.dpz.es/recursos/publicaciones/33/63/10armillas.pdf (access data: 10.06.2016). (In Spanish).

Borges Morán, P. (1995) Inspiración americana de la Utopia de Tomás Moro. Mar Oceana: revista del bumanismo español e iberoamericano, no. 2, pp. 91-111. (In Spanish).

Briesemeister, D. (2000) Las cartas de Amerigo Vespuci sobre el Nuevo Mundo. Olivar, vol. 1, no. 1, pp. 43-64 [online] Avalable at: http://www.olivar.fahce.unlp.edu.ar (access data: 04.09.2015). (In Spanish).

Buber, M. (1966) Caminos de utopía. México, FCE. 204 p. (In Spanish).

Cerutti, G. H. (1996) Teoría de la utopía? In: Agüero, O. and Cerutti, H. (eds.). Utopía y nuestra América. Quito, Ed. Abya-Yala. 108 p. P. 93-108. (In Spanish).

Colón, C. La Carta de Cristóbal Colón anunciando el descubrimiento. Antologia del Ensayo [online] Avalable at: www.ensayistas.org/antologia/XV/colon/ (access data: 01.06.2016). (In Spanish).

Galimidi, J. L. La verdad y su recepcion en Utopía de Tomás Moro. UDESA - Universidad de San Andrés [online] Avalable at: http://live.v1.udesa.edu.ar/files/UAHumanidades/EVENTOS/PaperGalimidi101207.pdf (access data: 01.06.2016). (In Spanish).

Imaz, E. (1982) Topía y Utopía en Utopías del Renacimiento (1a. ed. 1941). Estudio preliminar. In: Utopias del renacimiento: Utopia, La Ciudad del Sol, Nueva Atlantida. Mexico, Fondo de Cultura Económica. P. 7-25. (In Spanish). 
Kateb, G. (1972) Utopia and Its Enemies: Studies in the Libertarian and Utopian Tradition. New York, Schocken Books. 244 p.

Krismansky, H. J. (1963) Die utopische metod. Koln; Opladen, Westdentscher Verlag. 159 s. (In Germ.).

Martinez Estrada, E. (1963) El Nuevo Mundo, la isla de Utopia y la isla de Cuba // Cuadernos americanos. № 2. P. 89-122. (In Spanish).

Morgan, E. A. (1946) Nowheare was somewhere: How History makes Utopias and How Utopias make History. Chapel Hill, The University of North Carolina Press. 234 p.

Ramos, P. D. (1981-1982) Variaciones ideologicas en torno al Descubrimiento de America.Pedro Martir de Angleria y su mentalidad. Valladolid, Cuadernos Colombinos X. CasaMuseo de Colon \& Seminario Americanista. 84 p. (In Spanish).

Roig, A. A. (1987) La utopía en el Ecuador (Estudio, introducción y selección de Arturo Andrés Roig). Quito: Banco Central del Ecuador; Corp. Ed. Nacional. 468 p. (In Spanish).

Ruyer, R. (1950) L'Utopie et les utopies. Paris : Press Universitaires de France. 293 p. (In French).

Trousson, R. (1995) Historia de la literatura utópica. Viajes a paises inexistentes. Barcelona : Península. 384 p. (In Spanish).

Sargent, L. (1979) British and American Utopian Literature, 1516-1975. Boston, G. K. Hall $\&$ Co. $559 \mathrm{p}$.

Vespucio, A. (1985) El Nuevo Mundo. Viajes y documentos completos. Madrid, Akal. 144 p. (In Spanish).

Submission date: 12.06 .2016$.

Паниотова Таисия Сергеевна - доктор философских наук, профессор кафедры теории культуры, этики и эстетики Института философии и социально-политических наук Южного федерального университета. ААрес: 344065, Россия, г. Ростов-на-Аону, Анепровский пер., 116. Тел.: +7 (863) 250-72-77. Эл. адреc: tspaniotova@mail.ru

Paniotova Taissia Sergeevna, Doctor of Philosophy, Professor, Department of Theory of Culture, Ethics and Aesthetics, Institute of Philosophy and Social and Political Sciences, Southern Federal University. Postal address: 116 Dneprovskiy Per., 344065 Rostov-on-Don, Russian Federation. Tel.: +7 (863) 250-72-77. E-mail: tspaniotova@mail.ru 